\title{
Lyricus Vates: Musical Settings of Horace's Odes
}

\section{Citation}

Tarrant R.J. 2012. Lyricus vates: musical settings of Horace's Odes. In Reception and the Classics (Yale Classical Studies 36), ed. William Brockliss, Pramit Chaudhuri, Ayelet Haimson Lushkov and Katherine Wasdin, 72-93. Cambridge: Cambridge University Press.

\section{Permanent link}

http://nrs.harvard.edu/urn-3:HUL.InstRepos:8919560

\section{Terms of Use}

This article was downloaded from Harvard University's DASH repository, and is made available under the terms and conditions applicable to Other Posted Material, as set forth at http:// nrs.harvard.edu/urn-3:HUL.InstRepos:dash.current.terms-of-use\#LAA

\section{Share Your Story}

The Harvard community has made this article openly available.

Please share how this access benefits you. Submit a story.

\section{Accessibility}




\section{Lyricus Vates: Musical Settings of Horace's Odes}

\section{Richard Tarrant}

I first became aware of a connection between Horace's Odes and music as an undergraduate, when I read in Eduard Fraenkel's Horace that "not very long ago [i.e., from the perspective of the 1950s] it was the custom at many German schools to have the first stanza [of Odes 1.22, Integer vitae] sung at the funeral services in Hall, to a tune not distinguishable from that of an ordinary church hymn; the tempo, needless to say, was molto adagio."1 Fraenkel was referring to a musical setting of the poem by F. F. Flemming (1778-1813), which gained wide circulation in both English- and Germanspeaking countries. $^{2}$

Much more recently in an amateur choral group I performed a setting by Randall Thompson (1899-1984) of another solemn-sounding passage from the Odes, the final stanza of Odes 1.13, beginning Felices ter ("Three times happy"). ${ }^{3}$ While those two pieces represent a tiny and purely random sample of a large body of Horatian musical settings, they nevertheless share what we shall find to be several recurring features of the Odes' reception in music: they select a portion of an ode rather than setting the entire poem, they transform Horace's individual voice into a choral utterance, and they turn texts that are playful or ironic in their original context into morally uplifting statements. ${ }^{4}$ In other words, they are in significant respects unfaithful to their Horatian originals. Those alterations in turn suggest that the Odes, although they have proven attractive to composers, are at the same time in some ways resistant to musical treatment.

The impact of Horace's Odes on Western music since the Renaissance cannot compare with that of, for example, the various episodes of Ovid's Metamorphoses, but 
Horace can claim the distinction of having had his own words, in Latin or in translation, set to music more often than any other classical author. The musical aspect of his reception has received little attention in recent companions and other works in English, a neglect that is sadly true of many studies of classical reception. ${ }^{5}$ Fortunately, any investigation of the subject can draw on two indispensable guides: a splendid survey by Franco Piperno in the Enciclopedia Oraziana, ${ }^{6}$ and an anthology of musical settings edited by Joachim Draheim and Günther Wille that brings together examples ranging from the Middle Ages to the 1970 s. $^{7}$ The following discussion is of necessity highly selective; I have favored material that has not been treated in detail in earlier discussions, and I have often been guided in my choices by the availability of recordings. ${ }^{8}$

A link between the Odes and music would seem perfectly natural, given that the genre in which Horace was writing was in its Greek origins meant for musical performance and Horace himself employs the language of musical accompaniment to describe his poetry. (Cf., e.g., Odes 1.1.32-4 si neque tibias / Euterpe cohibet nec Polyhymnia / Lesboum refugit tendere barbiton, "if Euterpe does not withhold her flute and Polyhymnia does not refuse to tune the Lesbian lyre.") At least one lyric composition of Horace was intended for actual performance, the Carmen Saeculare commissioned by Augustus for the grand celebration of the Secular Games (Ludi Saeculares) of $17 \mathrm{BC}$ and sung by twin choruses of twenty-seven boys and twenty-seven girls; it is inconceivable that the poem was performed without some form of musical accompaniment. ${ }^{9}$ The Carmen, however, is clearly exceptional in its occasional and public character, and I know of no reliable evidence for musical performances in antiquity of Horace's collections of lyric poetry. ${ }^{10}$ 
Musical settings of the Odes are first attested in the Middle Ages, and are in fact as old as the Horatian manuscript tradition itself: the earliest extant manuscript, Vatican Reginensis latinus 1703, probably written in Alsace in the second quarter of the ninth century, marks the opening line of Odes 1.1 (Maecenas atavis edite regibus) and lines 5-8 of Odes 1.3 with the medieval musical notation known as neumes; similar notation, either of parts of odes or of entire odes, has been found in almost fifty Horatian manuscripts from the ninth through the twelfth centuries. ${ }^{11}$ Recent work by the late Silvia Wälli and by Jan Ziolkowski has given us a much clearer, but also more complex, picture of the phenomenon of neuming and its possible motivations. As far as the Odes are concerned, the likeliest explanation for the practice is that the musical notation was meant to serve a scholastic purpose, making Horace's complex and varied lyric meters easier to analyze and remember. That function, however, would not account for the frequent neuming of passages from works of Virgil, Lucan, and Statius written in the more familiar dactylic hexameter; in such cases neuming may have been intended to focus attention on passages of high emotion (e.g., speeches) or on pivotal points in the narrative, perhaps as an aid to effective declamation. ${ }^{12}$

One neumed manuscript of Horace can boast a connection (even if probably a tangential one) with a momentous development in the history of western music. In Montpellier, Ecole de Médecine 425H, written in the eleventh century, Odes 4.11 (Est mihi nonum superantis annum) is neumed with the same melody used by Guido of Arezzo shortly before as a mnemonic device for teaching the ascending notes of the scale. Guido connected the melody to the text of a famous hymn in honor of John the 
Baptist attributed to Paul the Deacon (late eighth century), of which the first stanza is as follows:

\author{
Ut queant laxis resonare fibris \\ mira gestorum famuli tuorum, \\ solve polluti labii reatum, \\ Sancte Ioannes.
}

(So that your servants may sound forth

the wonders of your deeds with loosened hearts, remove the guilt of our tainted lips,

\title{
Saint John.)
}

Since each half-line of the first three verses begins on a progressively higher note, Guido used the first syllable of each half-line to generate the series $u t-r e-m i-f a-s o-l a$. With $u t$ replaced by $d o$ and with the addition of $t i$ and a second $d o$ to complete the octave, Guido's mnemonic forms the basis of the solfège or solmization system still in use today.$^{13}$ Most scholars believe that the melody in question was first used for Ut queant laxis and later transferred to the Horatian ode,${ }^{14}$ but in the absence of a neumed text of $U t$ queant laxis the question cannot be definitively resolved; there has even been wishful speculation that the tune originated with Horace himself. ${ }^{15}$

A desire to impart metrical instruction undoubtedly prompted some of the earliest post-medieval musical treatments of the Odes, produced in German humanist circles in the years around 1500 under the leadership of Conradus Celtis and his student the 
composer Petrus Tritonius (a name presumably bestowed before the tritone became stigmatized as the diabolus in musica). In these settings the musical line is clearly subordinate to the text and reproduces the metrical shape of the Latin, and since Latin prosody differentiates only between long and short syllables, the corresponding musical note values are limited to a single binary opposition (whole vs. half-notes, or half-notes vs. quarter-notes). The possibilities for musical expression are therefore severely limited; perhaps the most that could be accomplished within such a system is illustrated by some reharmonizations of Tritonius' settings by Ludwig Senfl (c. 1486-1542/3), one of the leading composers of the early sixteenth century. ${ }^{16}$

By the mid-sixteenth century, metrically determined settings had largely given way to freer treatments in which the text was interpreted without regard for the quantitative values of the syllables. The middle decades of the sixteenth century arguably represent the high point of Horace's prestige among musicians: at this time various odes and epodes were set by several eminent masters, including Claude Goudimel (settings of nineteen odes, published 1555, unfortunately lost), Jacob Arcadelt (Odes 1.22 Integer vitae, 1.32 Poscimus, si quid and 3.22 Montium custos, all in Sapphic meter, published 1559), ${ }^{17}$ Orlando di Lasso (setting of Epode 2, Beatus ille), and Cipriano de Rore (setting of Odes 3.9, to be discussed shortly). The musical form employed for most of these settings was the motet, a choral treatment of a text (usually fairly short) in a richly polyphonic style, scored for ensembles of between four and eight voices. The majority of motet texts were drawn from sacred scripture, and so the use of motet form for classical poetry was itself a sign of the high prestige enjoyed by canonical classical authors. The work most frequently represented is the Aeneid, and within that poem the passage most 
often chosen is Dido's last speech before her suicide, beginning "Dulces exuviae," a text set by every significant choral composer of the century. ${ }^{18}$

Of the Horatian compositions from this time the most imposing is Cipriano de Rore's setting of Odes 3.9, Donec gratus eram tibi. The ode is unusual in presenting a dialogue between a woman (named Lydia) and a man (not named, and presumably Horace). They had been lovers but each is now involved with someone else; in a sequence of three paired stanzas in which the man speaks first and the woman responds, they recall their past happiness together, heap praise on their current partners, but in the end agree to resume their relationship. Rore's setting appears in a sumptuous choirbook commissioned by Duke Albrecht V of Bavaria and completed in 1559; the book is now Mus. MS B in the Bayerische Staatsbibliothek in Munich. The setting of Odes 3.9 occupies a place of honor near the opening of the book, following a Marian text and a setting of Dido's speech to Aeneas beginning "Dissimulare etiam" (Aen. 4.305-19).$^{19}$ It is scored for two four-voice choirs, one of low voices representing the male speaker and the other of high voices representing the female. As a close study by Jessie Ann Owens has shown, Rore's work is remarkable for its fidelity to Horace's text: the musical lines reflect the shape of the asclepiad rhythm (though with some liberties to permit more natural musical phrasing), the vocal writing is often homophonic (i.e., all voices sing the same words), allowing the words to be more clearly understood ${ }^{20}$ and the settings of the individual stanzas are subtly varied to convey both the parallelisms and movements of the characters' exchanges. ${ }^{21}$ One detail may be singled out to show how carefully Rore had studied the text: at the opening of the man's last stanza, where quid si ("what if") introduces his cautiously phrased proposal of a reconciliation, Rore gives quid a longer 
note value than the corresponding words carry in the previous stanzas, drawing attention to that crucial moment in the action.

In one important respect, though, Rore imposes an alien interpretation on the poem: after stanzas five and six have been sung by the respective male and female choirs, both groups join to repeat the woman's last words, tecum vivere amem, tecum obeam libens ("I would love to live with you and with you I would gladly die"). The writing also becomes exuberantly polyphonic at that point, to suggest a joyous release after the strictly controlled exchanges that have preceded. While this closural gesture is undeniably effective in musical terms, it sacrifices the emotional restraint and astringency that distinguish Horace's poem. ${ }^{22}$

My examples so far have all been choral in form, reflecting the Renaissance preference for choral music as the medium for serious expression. England in the late sixteenth and early seventeenth centuries produced a large body of solo song, to be accompanied either by lute or by a small consort of strings. The largest concentration of Horatian material from that period is in the work of John Wilson (1595-1674), who received his doctorate in music at Oxford in 1644 and was the first Heather Professor of Music there from 1656 to 1662 . Wilson's songbook, a manuscript containing 226 items, is now in the Bodleian Library (Mus. B 1); it includes settings of eighteen Horatian odes (plus Epodes 2 and 7), along with other Latin texts by Petronius, Statius, Martial, Claudian, and Ausonius; the epilogue to Ovid's Metamorphoses (15.871-8) concludes the collection. Like his selection of Latin authors, Wilson's choice of odes is remarkable for its range: in addition to already established favorites such as $1.11,1.22$, and 3.9, he included such rarely set items as the hymn to Mercury (1.10), Persicos odi (1.38), 
Diffugere nives (4.7, the earliest musical setting I know of), and even one of the so-called Roman Odes (3.3), which have on the whole deterred composers because of their length and unremittingly earnest tone; in fact Wilson's setting confines itself to the first two stanzas. ${ }^{23}$ Wilson's straightforward musical treatments are not as varied as his choice of texts, and his versions do not capture the shifting tone of a poem such as Diffugere nives. His expressive devices are limited to placing emphasis on emotionally significant words, such as interitura ("doomed to die") and pulvis et umbra sumus ("we are dust and ash") in 4.7.10 and 16. There is in general a stiffness about his settings that contrasts sharply with the freedom displayed in contemporary songs on English texts, e.g., those by Henry Lawes. The most persuasive case possible for Wilson's Horatian settings has been made in a recording by Emma Kirkby, long a leading figure in the British early music world, whom I recall meeting in one of Eduard Fraenkel's seminars, when she was an Oxford undergraduate reading Classics. Many years later, in recognition of her continuing interest in the Classics, the Classical Association of the UK elected her its Honorary President, and in lieu of the customary presidential address Dame Emma gave a presidential recital of works based on Greek and Latin texts - a practice that our own APA is, unfortunately, not likely to emulate. ${ }^{24}$

Horace's musical profile in the seventeenth and eighteenth centuries was less conspicuous than during the Renaissance, in part because of the growing popularity of opera, not a form hospitable to Horatian lyric - although Piperno does make a tantalizing reference to an 1868 Paris operetta by Montauby with Horace himself as its protagonist. ${ }^{25}$ The more modest form of the cantata was more amenable to Horatian material, especially when presented in Italian translation. In England the composer-impresario Giovanni 
Gualberto Bottarelli, a prominent figure in the musical life of London in the decades following the death of Handel, organized two collections of cantatas based on the Odes, the first in 1757 containing twelve pieces and a sequel in 1775 containing six items. For each collection Bottarelli enlisted a sextet of composers, of whom the best known today were William Boyce and Thomas Arne in the first group and Johann Christian Bach in the second. ${ }^{26}$ These works are notable for their emphasis on lighter, erotic themes, in contrast to much of Horace's earlier musical reception, in which he figures primarily as a moralist. ${ }^{27}$ Some of these works should be considered as paraphrases or even looser treatments of Horatian material rather than settings in the strict sense: so, for example, J. C. Bach's "O Venere vezzosa" (based on Odes 1.30$){ }^{28}$

The late eighteenth- and nineteenth-century development of the solo art song (the Lied in its German incarnation), based on poetic texts often in stanza form, might seem to be the ideal moment for a major musical exploration of the Odes. It is tempting to think what Mozart, for example, might have made of Donec gratus eram tibi (3.9), an ode sometimes described as "Mozartian" because of its graceful movement and its impression of serious feeling at work beneath a highly polished surface.$^{29}$ By that time, however, classical texts no longer enjoyed the currency of earlier periods; furthermore, the ostensibly simple and direct style found in most Lieder texts of the Romantic period is the polar opposite of Horace's highly wrought and verbally complex lyric manner. It is possible that some Horatian motifs appear in poems of, e.g., Goethe (a keen admirer of Horace) that were set to music, but I know of no Lieder that are settings of actual Horatian texts. ${ }^{30}$ 
Instead Horace's musical reception in nineteenth-century Germany is predominantly once more choral, in works composed for the many amateur choral societies established at the time. That is the context from which pieces such as F. F. Flemming's Integer vitae emerged. ${ }^{31}$

Flemming's hymn-like setting is a good match for the ode's first stanzas:

Integer vitae scelerisque purus

non eget Mauris iaculis neque arcu

nec venenatis gravida sagittis,

Fusce, pharetra,

sive per Syrtis iter aestuosas

sive facturus per inhospitalem

Caucasum vel quae loca fabulosus

lambit Hydaspes.

("The man of upright life, devoid of crime, can do without Moroccan spears or a bow and quiver laden with poisoned arrows, my dear Fuscus, whether he makes his way through the scorching Syrtes or the forbidding Caucasus or the places washed by the Hydaspes, river of legend.")

As the poem proceeds, however, the high moral tone of the opening is progressively undermined. In the middle two stanzas Horace supports his general statement with a purported piece of autobiography: one day as he was wandering unarmed in the woods singing of his girlfriend Lalage (whose name suggests "The 
Prattler"), a ferocious wolf ran from him. The closing pair of stanzas draws the moral: place him anywhere on earth, in arctic cold or equatorial heat, Horace will go on - not being integer vitae, but loving Lalage. The poem pokes gentle fun at the skewed logic of the besotted lover, while its concluding description of Lalage (dulce ridentem ... dulce loquentem "sweetly smiling, sweetly talking") glances ironically at a famous poem of Catullus - in its turn a translation of an ode of Sappho - that presented a much more serious picture of a lover's obsession. ${ }^{32}$

At nearly the same that the young Eduard Fraenkel was hearing Flemming's setting of Integer vitae sung at school funerals, the Harvard Sanskrit scholar C. R. Lanman remarked on the same practice in his own academic community. (Lanman cited it as a parallel to changes he believed had been made to Vedic texts for similarly incongruous ritual purposes.) His comments are worth quoting in full:

During the last twenty-four years, I have often been called to the University Chapel to pay the last tribute of respect to one or another departed colleague or friend. On such occasions, it frequently happens that the chapel choir sings the first two stanzas of the Horatian ode (i.22), integer vitae scelerisque purus, to the stately and solemn music of Friedrich Ferdinand Flemming. Indeed, so frequent is the employment of these words and this music, that one might almost call it a part of the "Funeral Office after the Harvard Use." The original occasion of the ode, and the relation of Horace to Aristius Fuscus to whom it is addressed, are fairly well known. The lofty moral sentiment of the first two stanzas, however seriously Horace may have entertained it, is doubtless uttered in this connection in a tone of mock-solemnity. Even this fact need not mar for us the tender associations made 
possible by the intrinsic appropriateness of these two pre-Christian stanzas for their employment in a Christian liturgy of the twentieth century. But suppose for a moment that the choir were to continue singing on to the end, even to Lalagen amabo, dulce loquentem! ["I will go on loving Lalage, with her sweet talk"] what palpable, what monstrous ineptitude! If only the first two stanzas were extant, and not the remaining four also, we might never even suspect Horace of any arrièrepensée in writing them; and if we were to interpret them simply in the light of their modern ritual use, how far we should be from apprehending their original connection and motive! $!^{33}$

Perhaps not surprisingly, Flemming's Integer vitae tune enjoyed another life as a hymn set to various English words. To a text by Elizabeth Charles (c. 1858) beginning "Praise ye the Father for his lovingkindness," it appeared in the Congregational Psalmist of 1875 , and to a text by Charlotte Elliott (1789-1871) beginning "O holy Saviour, friend unseen," it occupied a place in the Harvard University Hymn Book from 1926 to $1964 .^{34}$

In the realm of the French art song, among isolated settings by Jules Massenet and Camille Saint-Saëns, the most conspicuous use of Horace is the collection of ten songs entitled Etudes latines, written in Rome and published in 1900, by Reynaldo Hahn (18741947), a composer born in Caracas who spent almost the whole of his life in Paris and whose music is now enjoying a modest revival of interest, especially in Great Britain. ${ }^{35}$ The texts of Etudes latines are drawn from a collection of the same name comprising eighteen poems by the Parnassian poet Leconte de Lisle (1818-1894), first published in 1852 as part of a larger collection of Poèmes antiques. The poems are not translations of Horace, ${ }^{36}$ but reworkings of Horatian characters and themes, as is suggested by several of 
the titles: e.g., "Thaliarque" recalls the addressee of Odes 1.9, as "Pyrrha" does that of 1.5 and "Phyllis" that of $4.11 .^{37}$ Exhortations to drink and enjoy the moment are frequent, as in these lines from the opening poem, "Lydie": "ceignon nos cheveux blancs de couronnes de roses; / buvons, il en est temps encore, hâtons-nous!" Hahn's settings are in a style influenced by Gabriel Fauré and Henri Duparc $;^{38}$ one is dedicated to Fauré and another to Hahn's close friend Marcel Proust. Their mood is predominantly gentle and subdued, with frequent markings such as "calme," "tendre," "modéré" and "sérieux." Hahn's cycle has fared well on recordings: there are complete versions by Ian Bostridge and Stephen Varcoe $^{39}$ and by Bruno Laplante..$^{40}$

Almost all musical settings of Horace prior to the twentieth century, whether based on the original Latin or a translation, aim at an effect that can be described as contemporary: they adapt Horace to the musical style of the period, whether that style is that of a sixteenth-century polyphonic motet or a nineteenth-century German Männerchor. In the twentieth century, by contrast, a number of composers have chosen to set Horace's Latin in conscious imitation of an earlier style, as a way of highlighting its otherness. (A similar use of Latin for its distancing effect can be seen in Stravinsky's Oedipus Rex and in Carl Orff's cantatas based on Catullus and the medieval Carmina Burana.) One exemplar of this deliberately archaizing approach is the American composer Randall Thompson, best known for his choral writing; his Alleluia (1940) is among the most often-performed choral works of the century. ${ }^{41}$ Thompson cultivated a lifelong interest in the musical styles of earlier periods, especially sixteenth-century polyphony; in an informal set of reflections composed near the end of his life he wrote “my heart still leaps up when I see a cantus firmus."42 Among his earliest published 
compositions are settings of five odes of Horace, written in 1924-25 during his tenure of a Rome Prize at the American Academy. ${ }^{43}$ They show the influence of Thompson's mentor Gian Francesco Malipiero, who at the time was immersing himself in the music of Monteverdi and his contemporaries. Almost thirty years later, in 1953, as a tribute to his Harvard teacher and colleague Archibald T. Davison on his retirement, Thompson returned to the Odes and composed a four-voice setting in the style of Palestrina of the final stanza (lines 17-20) of Odes 1.13:

\section{Felices ter et amplius}

quos inrupta tenet copula nec malis divulsus querimoniis suprema citius solvet amor die. (Three times happy they, and more, who are held in an unbroken bond, whose love, divided by no bitter quarrels, will not loose them before their last day. $)^{44}$

For Thompson, the text must have seemed appropriate as a way to express his affection for the work's dedicatee ${ }^{45}$ he also recalled that he chose it because it appeared as an inscription on one of the gates leading into Harvard Yard. ${ }^{46}$ In its original Horatian context, though, the stanza is considerably more problematic, and interesting. In the four stanzas that precede it, Horace details his jealous reactions when he hears Lydia (a former lover?) praising her boyfriend Telephus. His rage and despair are described in terms that strongly suggest parody of conventional love poetry. The swerve into apparent high 
seriousness in the closing lines thus presents the reader with a challenge of interpretation: is Horace setting an ideal vision of love against a foolishly romantic version, is he showing Lydia a kind of love she has no chance of enjoying with Telephus, or is he ruefully reflecting on what he himself had failed to achieve in his relationship with her? ${ }^{47}$ This complexity disappears entirely when the final stanza is detached from its setting and read (or sung) in isolation. ${ }^{48}$

Even this highly selective discussion makes it clear that Horatian lyric has appealed to a wide range of composers over a long span of time. But surveying how the odes have been set also makes us more aware of the difficulties they pose for musical treatment. The verbal density of Horace's writing is one obstacle; another is the awkwardness of his preferred line-lengths for modern musical styles. Many odes are too long to be comfortably set, especially if the musical handling is to have any complexity or richness. But perhaps the greatest challenge is posed by the variety of tone and content that Horace often encompasses within a single ode, a variety made all the more striking by the repetition of the same metrical patterns throughout a poem. One of Horace's best modern critics has written that "to cover ground is a merit in a poet," repeating stanzaic base does not readily express such differences of mood within a piece. ${ }^{50}$ Those features, the last in particular, help to explain why so many settings have been made of parts of odes or even of individual stanzas, in which the musical treatment could evoke a single emotional mood, even if one not consistent with the Horatian text as a whole. ${ }^{51}$ In this as in other respects, Horace's lyric poetry, which appears so direct and approachable, turns out to be stubbornly elusive. 
Musicians are not the only readers of Horace who have plucked lines and stanzas out of their context in order to give them a more straightforward meaning. The same impulse lies behind the creation of anthologies of poetic excerpts, or florilegia, of which numerous examples survive from the Middle Ages and the early modern period. As it happens, both Odes 1.13.17-20 (Felices ter) and 1.22.1-8 (Integer vitae) appear in some manuscripts of the most widely circulated medieval anthology of excerpts from classical poetry, known as the Florilegium Gallicum; the former passage is listed under the heading De concordia coniugali ("On marital harmony") and the latter is headed Que sunt commoda innocentie ad amicum ("The advantages of innocence, to a friend"). ${ }^{52}$

Perhaps because of the difficulties that Horace's Latin lyrics pose for musical setting, a closer approach in music to the spirit of the Odes can sometimes be achieved by a less immediate relationship to their text. That is to say, the Horatian ethos may be better reflected in musical settings of texts that are either inspired by Horace or compatible with his lyric voice, but whose form offers composers a more accessible basis for their music.

One example is provided by the poetry of A. E. Housman (1859-1936). Although Housman's famous translation of Odes 4.7, Diffugere nives (“The snows are fled away"), first published in 1897 and included in More Poems (1936), does not yet seem to have attracted any composer's attention, the brevity and verbal directness of Housman's own poems have prompted musical settings by the hundreds. ${ }^{53}$ Among the most successful of Housman settings are the cycle On Wenlock Edge by Ralph Vaughan Williams (18721958), consisting of six poems from A Shropshire Lad, composed in 1908-09, and the two collections by George Butterworth (1885-1916), Six Songs from A Shropshire Lad (1909-11) and Bredon Hill and Other Songs (1912). In contrast to the liberties that many 
musical settings of Horace have taken with the poems, Housman settings are remarkable for their fidelity to the text-in part, to be sure, because of the poet's well-known sensitivity on that point..$^{54}$

Housman's faux-naïf diction has little in common with Horace's style, but he often deals with Horatian themes, such as the use of images from nature to reflect human mortality. In the opening of "On Wenlock Edge" that motif is combined with a direct allusion to Horace: "On Wenlock Edge the wood's in trouble" points to the opening stanza of Odes 1.9 (Vides ut alta), describing the snow on Mt. Soracte, and specifically the phrase nec iam sustineant onus / silvae laborantes (1.9.2-3), "the toiling woods no longer bear the weight." After that opening gesture, it cannot be coincidental that the poem goes on to connect the speaker with a nameless Roman who looked upon the same woods in ancient times. In the lines "The tree of man was never quiet: / Then 'twas the Roman, now 'tis I," Housman seems almost to be advertising the Horatian pedigree of his thought.

Housman's manipulation of stanza form sometimes shows similarities to Horatian practice. "Is my team ploughing" resembles Donec gratus eram tibi (Odes 3.9) in representing a dialogue in which each pair of stanzas is divided between speaker and respondent. The speaker is a dead man who wishes to know how life is proceeding now that he is gone; in the first three pairs of stanzas he is told (by whom is not immediately clear) that all those to whom he was close have quite forgotten him. As in Horace's ode, the final pair of stanzas introduces an unexpected twist:

"Is my friend hearty,

Now I am thin and pine, 
And has he found to sleep in

A better bed than mine?"

Yes, lad, I lie easy,

I lie as lads would choose;

I cheer a dead man's sweetheart,

Never ask me whose..$^{55}$

Butterworth's setting is for a single voice; the speakers are distinguished by tempo and dynamic markings, molto moderato and pianissimo for the ghostly questioner and poco più mosso ("a little faster") and forte for the robust survivor. As is his usual practice, Butterworth employs the same melodic material for each pair of stanzas; in this case the musical repetition suits the similar question-and-answer structure of the verses. Only in the final phrase, "never ask me whose," does Butterworth vary the vocal line, mirroring the sharp turn taken by the text at that point.

Another aspect of Horatian structural composition occasionally seen in Housman is what I have elsewhere described, borrowing a term from musical structure, as a $d a$ capo effect, an ABA arrangement of themes in which the concluding section of a poem seems to announce a return to the opening while introducing a significant new element. ${ }^{56}$ A powerful example in Housman is "Bredon Hill," which opens with the sound of church bells ringing:

In summertime on Bredon

The bells they sound so clear; 
Round both the shires they ring them,

In steeples far and near,

A happy noise to hear.

The speaker recalls how he and his sweetheart would hear the bells as they lay together, and how he looked forward to having them peal at their wedding; instead his lover died and "went to church alone ... and would not wait for me." The last stanza begins with a compressed echo of the first:

The bells they sound on Bredon, And still the steeples hum.

“Come all to church, good people,"-

But at that point the speaker bursts out with a cry of exasperation:

Oh, noisy bells, be dumb;

I hear you, I will come. ${ }^{57}$

Vaughan Williams brings out the da capo character of the last stanza by his tempo marking (tempo alla prima, "tempo as at the beginning") and repeats the vocal part of the first stanza almost unchanged for the first three lines, making the impassioned outcry that follows even more shocking. ${ }^{58}$

An example from another poet and composer that provides an even more compelling illustration is the first of Benjamin Britten's Five Flower Songs (op. 47, from 1950), to a text by Robert Herrick, "To Daffadills." The content of the poem parallels that of Horace's ode to Leuconoe (1.11 Tu ne quaesieris), the source of what is today Horace's most familiar phrase, carpe diem. The form of Horace's poem corresponds 
mimetically to its theme: it is noticeably short (11 lines) and is composed in a meter remarkable for a succession of three choriambs (a metrical unit with the shape long/short/short/long), which creates an impression of almost breathless speed. Herrick develops the underlying metaphor in carpe diem, of the day figured as a flower that soon withers and dies, while his short phrases capture the rapidity of Horace's metrical scheme.

Faire Daffadills, we weep to see

You haste away so soone:

As yet the early-rising Sun

Has not attain'd his Noone.

Stay, stay,

Untill the hasting day

Has run

But to the Even-song;

And, having pray'd together, we

Will goe with you along.

We have short time to stay, as you,

We have as short a Spring;

As quick a growth to meet Decay,

As you, or any thing.

We die,

As your hours doe, and drie

Away, 
Like to the Summers raine;

Or as the pearles of Mornings dew

Ne'r to be found againe.

Britten's setting conveys the sense of swiftly passing time primarily through the choice of tempo. He marks the first stanza "Allegro Impetuoso," a rare (and possibly ad hoc) tempo indicator that highlights the quickly-moving setting of the words. The second stanza bears the marking "Sempre Allegro," and the pace does not slacken until the last four bars, with a "rall[entando]" that corresponds to the final word, "againe," which is repeated several times. In a performance that gives Britten's tempo markings their full weight, the song is over almost before the listener knows it has begun - an effect that produces in music an effect comparable to what Horace expresses in words: dum loquimur, fugerit invida / aetas ("while we speak, spiteful time has fled") ${ }^{59}$ Here for once a Horatian sentiment has found a fully appropriate musical equivalent. ${ }^{60}$

\section{The Carmen Saeculare}

The musical fortunes of the Carmen Saeculare in modern times are themselves a rewarding object of study. For such a quintessentially occasional poem, the Carmen has proven remarkably adaptable to a variety of contexts and purposes ${ }^{61}$ The composers who are said to have set it, in whole or in part, include François-André Danican Philidor, Carl Loewe, ${ }^{62}$ Georges Bizet, Max Reger, ${ }^{63}$ Gian Francesco Malipiero, and (at one remove) Giacomo Puccini. 
The setting by Philidor, which received its first performance in London in 1779, remains by far the most ambitious musical composition ever based on Horace's poetry; in its pomp it may well have exceeded the original performance of the Carmen, at the Ludi Saeculares of $17 \mathrm{BC}^{64}$

The moving spirit behind the enterprise was Joseph (né Giuseppe) Baretti (17191789), a writer and critic with close ties to Samuel Johnson and other prominent literary and artistic figures of the time: when Baretti was tried for murder in 1769, he was able to enlist Johnson, Edmund Burke, Oliver Goldsmith, Joshua Reynolds, and David Garrick as character witnesses for his (successful) defense. Baretti's introductory pamphlet to his translation of the Carmen laments the neglect of Horace by contemporary composers: "whenever I happened to look into those Odes, I have wondered at the inattention of our Composers, who ever since the invention of modern Musick, have been hunting every where for harmonious verses, yet never bethought themselves of Horace's, which in point of harmony, as well as other excellence, are, by universal confession, superiour to any thing of the kind produced these two thousand years." ${ }^{65}$

Determined to give the Carmen Saeculare a suitable modern musical treatment, Baretti went in search of a composer: "I wanted a man of sense, a man of taste, a man of enthusiasm, fertile in ideas and expedients, and able to temper alternately the solemnity of church-musick with the brilliancy of the theatrical." ${ }^{66}$ He thought he had found his man in Philidor (1726-1795), a frequent visitor to London whose previous compositions included a comic opera based on Fielding's Tom Jones. ${ }^{67}$

Philidor's Carmen Saeculare is a full-length oratorio, only the last section of which is a setting of the Carmen proper. It is preceded by several other texts from the 
Odes with related themes, arranged to produce a quasi-narrative sequence. The main sections are as follows: Prologue, "The Poet bespeaks the attention of the hearers by the greatness of his subject" (Odes 3.1.1-4 Odi profanum vulgus et arceo etc.); Part I, "The Poet exhorts the young Singers of both sexes to sing his verses well" (Odes 4.6.29-44); Part II, "Both Choirs implore of Apollo to approve and protect the Secular Song" (Odes 4.6.1-28); Part III, "The Boys and Maidens, forming two choirs, encourage each other to sing the praises of Apollo and Diana" (Odes 1.21); Part IV, "Prayers for the prosperity of the Empire and the Emperour" (Carm. Saec.). ${ }^{68}$

Aiming to avoid the potential for monotony in setting thirty-five stanzas of verse, Philidor divided the text into twenty-five musical numbers, allocating the Prologue and most of Part I to a tenor soloist representing the poet and in the remaining parts interspersing choral segments with solo arias, duets and quartets ${ }^{69}$ As a result, while a performance of the entire work takes up about ninety minutes, no single number much exceeds five minutes, and most are significantly shorter. The sequence of musical numbers, ending with a choral fugue, resembles the structure of Haydn's late oratorios (The Creation [1798], The Seasons [1801]), but Philidor operates at a much lower level of inspiration: instead of combining solemnity and flair, as Baretti had hoped, much of his music falls into a bland middle ground, graceful and well made, but instantly forgettable..$^{70}$

After initial success in London and Paris, and keen interest taken in the work by Empress Catherine the Great of Russia, Philidor's Carmen Saeculare fell into near-total oblivion. A recent recording ${ }^{71}$ has made the work once more accessible, but live performances will in all likelihood remain rare. 
In the nineteenth and twentieth centuries, the Carmen Saeculare was often understood in a wider sense as a timeless celebration of Rome and its glories. That may explain its appeal for the youthful Bizet, since he embarked on setting it during his tenure in 1857-60 of the Prix de Rome awarded by the Paris Conservatoire. The music is lost, and it is not clear if the work was even completed.

Malipiero's setting is the most ingenious in the use to which it puts Horace's poem. It forms the conclusion of his opera Giulio Cesare (1935, first performed 1936), loosely based on Shakespeare's play. In the final scene, following the battle of Philippi and the suicide of Brutus, the victorious armies of Antony and Octavian march onto the stage while the chorus declaims selected stanzas of the Carmen Saeculare. ${ }^{72}$ Whether or not Malipiero dedicated the work to Mussolini, as has been reported, ${ }^{73}$ its conclusion certainly reflects a pride in Romanità that is characteristic of the period.

The celebration of Romanità is also the motivating theme of Puccini's "Hymn to Rome" (Inno a Roma), composed in 1919 as part of post-World War I patriotic observances, and later enthusiastically adopted by the Fascist régime. (Puccini himself was candid about the work's shortcomings, describing it in a letter to his wife as "una bella porcheria," "a real piece of garbage.".74) Puccini's hymn is set to a text by Fausto Salvatori (1870-1929) that is only loosely connected to the Carmen Saeculare: it uses as a refrain the phrase "in all the world you [i.e., the Sun] will see nothing greater than Rome" ("Tu non vedrai nessuna cosa al mondo / maggior di Roma" = C.S. 11-12 possis nihil urbe Roma / visere maius) and has other less explicit echoes, but it is essentially an independent composition - though one that closely parallels the ethos of the Carmen. ${ }^{75}$ Puccini planned for it to be performed by several thousand singers (schoolchildren, 
soldiers, teachers, etc.) with several brass bands accompanying, but on the scheduled day, April 21 (the traditional birthday of Rome), the performance had to be cancelled because of a sudden rainstorm. The only recording I know of is not by a chorus but by Plácido Domingo accompanied by Julius Rudel on the piano, and in fact the writing (particularly the energico opening and the optional high A in the final phrase) seems to me better suited to a soloist than to a chorus, especially a large amateur group. Although it antedates the Fascist era, Salvatori's hymn could easily be mistaken for a product of that period, which shows how much Mussolini appealed to already potent nationalistic sentiments and to an idealized image of Italy as warlike but peace-bringing, harmonious, fertile and morally sound. That image is remarkably similar to the Augustan Italy evoked in Horace's poem, and Puccini's Inno may therefore serve as another example of a musical work at some remove from Horace that comes closer to the Horatian spirit than many works based more directly on his words. 


\section{Discography of recordings cited}

Collections of works by various composers are listed first, followed by recordings of works by individual composers.

"Classical Kirkby.” BIS CD 1435. 2002. Performed by Emma Kirkby (soprano) and Anthony Rooley (lute). Includes John Wilson, Diffugere niues (Odes 4.7) and Integer uitae (Odes 1.22).

"Dido’s Lament.” CD produced by Convivium Musicum. 2006. Performed by Convivium Musicum, dir. Scott Metcalfe. Includes settings of “Dulces exuviae” by Adrian Willaert, Marbriano de Orto, Josquin Desprez, and Jehan Mouton.

“Le Chant de Virgile.” Harmonia Mundi CD 901739. 2001. Performed by the HuelgasEnsemble, dir. Paul van Nevel. Includes Ludwig Senfl, Non usitata (Odes 2.20), Mollis inertia (Epode 14), and Petti, nihil me (Epode 11), Cipriano de Rore, Donec gratus eram tibi (Odes 3.9), and settings of "Dulces exuviae" by Josquin Desprez, Jehan Mouton, Marbriano de Orto, Jakob Vaet, Theodoricus Gerarde, and Orlando di Lasso.

“Rome's Golden Poets." CD produced by the chorus in conjunction with BolchazyCarducci Publishers. 1999. Performed by the St. Louis Chamber Chorus, dir. Philip Barnes. Includes Johann Walther, Felices ter (Odes 1.13.17-20), Jacob Handl, Principibus placuisse (Epist. 1.17.35) and Oderunt hilarem (Epist. 1.18.89-90), Peter 
Cornelius, $O$ Venus (Odes 1.30), Zoltán Kodály, Iustum et tenacem (Odes 3.3.1-8) and (arr.) Rectius vives (Odes 2.10.1-12), Randall Thompson, Felices ter (Odes 1.13.17-20), Vitas hinnuleo (Odes 1.23), Montium custos (Odes 3.22), and $O$ fons Bandusiae (Odes 3.13), Antonín Tučapsky, Ne forte credas (Odes 4.9.1-4), Iam satis terris (Odes 1.2.1-5), Nunc est bibendum (Odes 1.37.1-4), Eheu fugaces (Odes 2.14.1-4), and Tu ne quaesieris (Odes 1.11), and settings of "Dulces exuviae" by Adrian Willaert, Jacob Handl, and Josquin Desprez.

Benjamin Britten, Five Flower Songs, Op. 47. DG CD 453 433-2. 1997. Performed by the Monteverdi Choir, dir. John Eliot Gardiner.

George Butterworth, "Bredon Hill" and other songs and Six songs from "A Shropshire Lad.” Hyperion CD A67378. 2003. Performed by Christopher Maltman (baritone) and Roger Vignoles (piano).

Reynaldo Hahn, Etudes latines. Analekta CD 29402, a reissue of a recording made in 1974. Performed by Bruno Laplante (baritone) and Janine Lachance (piano).

Hyperion CD A67141-2. 1996. Performed by Ian Bostridge (tenor), Stephen Varcoe (baritone), and Graham Johnson (piano).

André-François Danican Philidor, Carmen Saeculare. Naxos CD 8.557593-94. 2007. Performed by the orchestra and chorus of Radio Svizzera, dir. Jean-Claude Malgoire, 
Giacomo Puccini, Inno a Roma. Columbia CD MK 44981. 1989. Performed by Plácido Domingo (tenor) and Julius Rudel (piano).

Ralph Vaughan Williams, On Wenlock Edge. Chandos CD 10465. 2008. Performed by Mark Padmore (tenor) and the Schubert Ensemble.

\footnotetext{
${ }^{1}$ Fraenkel (1957) 184. In a note he adds that the vocative Fusce in line 4 "very much puzzled me when I was a small boy."

${ }^{2}$ I return to Flemming and Integer vitae below, 000.

${ }^{3}$ See below, 000 .

${ }^{44}$ A good parallel for the un-ironic use of originally humorous music is the performance of Handel's aria "Ombra mai fu" from Serse, a love song addressed to a plane tree, as part of a funeral or memorial service.

${ }^{5}$ For recent studies of Horatian reception see, e.g., Harrison (2007) 277-346 and Houghton and Wyke (2009).

${ }^{6}$ Piperno (1998).
} 
${ }^{7}$ Draheim-Wille (1985). Thomas (1919-20) is also still useful. For information on individual composers I am largely indebted to Sadie (2001).

${ }^{8}$ Details of recordings mentioned are given in the Discography (000 below).

${ }^{9}$ On the Carmen Saeculare in its original ritual setting, see Feeney (1998) 32-8.

${ }^{10}$ For the surprisingly eventful musical afterlife of the Carmen Saeculare in modern times, see below, 000. The case for musical performance of the Odes in Horace's time has been argued most recently by Lyons (2010).

${ }^{11}$ Details of all manuscripts with photographs and transcriptions in Wälli (2002), for selected manuscripts in Lyons (2010) 132-75.

${ }^{12}$ On the range of possible reasons for neuming see Ziolkowski (2007) 109-72.

${ }^{13}$ See Ziolkowski (2007) 25-9. Photograph of Odes 4.11 in the Monpellier manuscript and transcription of the neumes in Wälli (2002) 156-9.

${ }^{14}$ So, e.g., Draheim-Wille (1985) 3. Lyons (2007) 26-40 argued instead that Guido found the inspiration for his mnemonic in the Montpellier manuscript, but that argument requires a pre-Guido dating of the manuscript that is unlikely on palaeographical grounds. Lyons (2010) 101-31 more cautiously suggests that Guido and the neumist of the Montpellier manuscript were drawing independently on a well-known melody of uncertain origin.

${ }^{15}$ A notion gently debunked by Thomas (1919-20) 78: "so at least people think who listen to it with the ear of faith."

${ }^{16}$ A specimen of Senfl's work can be heard in his setting of Odes 2.20 (Non usitata nec tenui ferar), recorded on the CD "Le chant de Virgile."

${ }^{17}$ The opening bars of Arcadelt's settings are given by Piperno (1998) 668 and 672. 
${ }^{18}$ Aeneid 4.651-8. The text was also frequently neumed in medieval manuscripts of Virgil; see Ziolkowski (2007) 149. The Boston-based early music group Convivium Musicum has recorded several settings of "Dulces exuviae," and other versions are included in the collections "Le chant de Virgile" and "Rome's Golden Poets." See below, 000.

${ }^{19}$ A facsimile of the first page of Rore's setting appears in Einstein (1949) vol. 2 following page 500 .

${ }^{20}$ The largely homophonic treatment is very different from Rore's usual polyphonic style, as seen in his madrigals.

${ }^{21}$ Owens (1983). She also provides a score.

${ }^{22}$ In contriving a final tutti Rore was anticipated by a 1554 setting by Francisco Portinaro of an Italian translation of the ode; cf. Einstein (1949) 2.474, Owens (1983) 99 n. 6. Rore's setting of Donec gratus eram tibi has been recorded in "Le chant de Virgile."

${ }^{23}$ As did a version for three-part male chorus by Zoltán Kodály from the 1930s, which I can only describe as glee-clubbish. (The piece can be heard on the CD "Rome's Golden Poets.") Odes 3.3.1-8 exerted a powerful attraction on Latin poets after Horace; see Tarrant (2007) 283-5 for discussion of related passages in Seneca, Prudentius, and Boethius.

${ }^{24}$ For details of "Classical Kirkby" see below, 000.

${ }^{25}$ Piperno (1998) 672. Montauby is a figure of impenetrable obscurity, who has no entry in The New Grove and is not mentioned in Bruyas (1974), a work that refers to nearly 1,400 French operettas. As Piperno notes, Horace makes a brief appearance in Puccini's La Bohème: in Act II, set in a crowded Paris square on Christmas Eve, the philosopher 
Colline voices his scorn for the holiday crowd with the words "Odio il profano volgo al par d'Orazio" ("I detest the vulgar throng as much as Horace did"), an allusion to Odes 3.1.1 Odi profanum vulgus.

${ }^{26}$ Bottarelli's 1757 collection included versions of Odes $1.5,1.8,1.13,1.19,1.20,1.22$, $1.23,1.26,1.30,1.32,1.38$, and 3.9. The composers represented were, in addition to Arne and Boyce, W. de Fesch, C. Heron, S. Howard, and J. Worgan. The 1775 collection comprised versions of Odes 1.13, 1.19, 1.22, 1.23, 1.30, and 1.32, and in addition to J. C. Bach contained compositions by G. Giordani, G. Boroni, M. Vento, I. Barthélemon, and I. Holzbauer.

${ }^{27}$ The conception of Horace as a moral teacher is in part a holdover from his medieval persona, which was based more on the Satires and Epistles than on the Odes.

${ }^{28}$ Score in Draheim-Wille (1985) 52-97.

${ }^{29}$ Cf. the comment of Johann Gottfried Herder (cited by Draheim-Wille (1985) 1): “wer wird nicht das unübertroffene 'Donec gratus eram tibi - Tecum vivere amem, tecum obeam libens' in einem Duett zu hören wünschen?" For the description "Mozartian” see Tarrant (1995) 49.

${ }^{30}$ Brahms's Sapphische Ode (published in 1884) sets a text by Hans Schmidt (18561923) whose form is that of the Sapphic stanza but whose content owes nothing to Horace (or Sappho).

${ }^{31}$ Flemming's setting may be found in Draheim-Wille (1985) 102.

${ }^{32}$ Dulce ridentem comes from Catullus (51.4-5 spectat et audit / dulce ridentem), but Horace adds dulce loquentem, not in Catullus but in Catullus' source, Sappho (31.3 $\hat{\alpha} \delta v$ $\phi \omega v \varepsilon i ́ \sigma \alpha \varsigma)$. On Horace's relation to Catullus here, cf. Putnam (2006) 32-5. Putnam reads 
Horace's poem more seriously than I would, as “a hymn to Lalage, which is to say, to inspiration" (34).

${ }^{33}$ Lanman (1905) 1xxvii.

${ }^{34}$ Hymn 252; the tune is named "Integer vitae" or "Flemming." Long before Flemming's time, a version of the Sapphic stanza - three lines of eleven syllables each, with word accent on the fourth, sixth and tenth syllables, followed by a line of five syllables with word accent on the first and fourth — had been used for Christian hymns, of which perhaps the best known is "Herzliebster Jesu," text by Johann Heermann (1630) and music by Johann Crüger (1640), harmonized by Bach in the St. Matthew Passion. ${ }^{35}$ In 1902 Hahn set a few lines of the Latin text of Odes 3.13 (O fons Bandusiae) as an independent composition; cf. Draheim-Wille (1985) 160-3. Sopranos and contraltos deliver lines 1 and 9-12 in a conspicuously plain manner, while a soprano solo performs elaborate melismas on the word "Ah!"

${ }^{36}$ Leconte de Lisle did translate Horace (1873), as well as the Greek tragedians, Homer, Hesiod, and Theocritus. His translation of Horace is in prose, and is surprisingly literal. ${ }^{37}$ There are also numerous verbal borrowings, as in the opening of "Phyllis": "Depuis neuf ans et plus dans l'amphore scellée / mon vin des coteaux d'Albe a lentement mûri" Odes 4.11.1-2 Est mihi nonum superantis annum / plenus Albani cadus ("I have a jar filled with Alban wine, more than nine years in aging”).

${ }^{38}$ One of the Etudes latines, "Lydie," had previously been set by Fauré and another, "Phidylé," by Duparc.

${ }^{39}$ A Hyperion CD (A 67141-2), issued in 1996.

${ }^{40}$ An Analekta CD (29402), a reissue of a recording made in 1974. 
${ }^{41}$ I chose to focus on Thompson because of local circumstances as well as musical factors. He taught at Harvard for many years and was Chair of the music department there from 1952-57; in that capacity he was responsible for the building of the Eda Kuhn Loeb Music Library, where much of the research for this paper was carried out. ${ }^{42}$ Thompson (1980) 16.

${ }^{43}$ The odes in question are $1.5,1.23,1.30,3.13$, and 3.22. They are all relatively short poems (none longer than sixteen lines), in keeping with Thompson's precept for choosing a text for musical treatment: "choose a good text and not too long a text" (Thompson (1980) 11). Performances of $1.23,1.30$, and 3.13 are included in "Rome's Golden Poets." ${ }^{44}$ The piece has been recorded on the CD "Rome's Golden Poets." ${ }^{45}$ Thompson had obviously forgiven Davison for denying him admission to the Harvard Glee Club during his undergraduate years.

${ }^{46}$ For those who know the area, it will be familiar as the Class of 1857 Gate, across from Holyoke Center and nearest the main entrance to the Harvard Square T stop. I have often wondered who was responsible for placing the Horatian inscription there and what relevance it was meant to have in its academic environment.

${ }^{47}$ One astute interpreter of Horace thought that the ending was deliberately ambiguous: “probably Horace intended the poem's close to leave us in uncertainty. He refuses, as he does so frequently, to allow us the satisfaction of restricting him to a single attitude" (Commager (1962) 155).

${ }^{48}$ The final stanza of Odes 1.13 had similarly been detached for musical treatment by the early Lutheran composer Johann Walther (1496-1570). Walther's piece was recorded on the CD "Rome's Golden Poets." 
${ }^{49}$ Nisbet (1962) 194.

${ }^{50}$ Rore's setting of Donec gratus eram tibi (above, 000) is a significant exception.

${ }^{51}$ Among many examples is one of the only passages of Horace set to music by a composer unquestionably of the first rank, three lines (41-3) of Odes 3.29 arranged as a three-voice canon by Franz Joseph Haydn: ille potens sui / laetusque deget, cui licet in diem / dixisse 'vixi' ("That man will live happy, his own master, who at the close of day can say 'I have lived'”); for the music see Deutsch (1959) 33. Haydn's tombstone bears a canonic treatment of a phrase of the following ode, non omnis moriar (3.30.6 "I will not wholly die"), apparently his favorite Horatian quotation.

${ }^{52}$ See Burton (1983) 278-9. The role of florilegia in guiding composers to isolated passages of Horace was acutely suggested by Philip Barnes in his notes to the CD “Rome's Golden Poets." For example, a florilegium is very probably the source of the single hexameter principibus placuisse viris non ultima laus est ("to have pleased the leading men is not the worst grounds for praise," Epist. 1.17.35), set to music by Jacob Handl (1550-1591), with a decidedly unclassical pentameter added to create an elegiac couplet: summa Deo laus est qui placuisse studet ("the highest praise belongs to the one who strives to please God").

${ }^{53}$ Nearly 400 musical settings of poems by Housman are listed by Gooch and Thatcher (1976); they include thirty-five separate settings each of "Loveliest of trees, the cherry now" and "When I was one-and-twenty." There is apparently a more recent catalog by Bill Lewis that lists almost 500 settings (referred to by Venables $(2008) 72,74)$, but I have not yet been able to locate it. 
${ }^{54}$ When Vaughan Williams dropped the two stanzas of "Is my team ploughing" referring to football, the poet was not pleased. He wrote his publisher, Grant Richards, "I am told that composers in some cases have mutilated my poems,- that Vaughan Williams cut two verses [sic] out of Is my team ploughing (I wonder how he would like me to cut two bars out of his music)." See Burnett (2007) 1.458. Housman even took offense when Butterworth, who had been given permission to set poems from A Shropshire Lad, thought he was therefore entitled to print the texts of the poems in a concert program. See Burnett (2007) 1.279.

${ }^{55}$ I cite the text from Burnett (1997) 29.

${ }^{56}$ On Horace's use of such a structure see Tarrant (1995).

${ }^{57}$ Text from Burnett (1997) 22-4. I understand the last line to mean that the speaker has no more reason to live and so can heed the summons of the bells to his own death.

${ }^{58}$ Butterworth also begins the last stanza with the same vocal line as the first, but since that line, or a slight variation of it, introduces each stanza, the da capo effect is much diminished.

${ }^{59} \mathrm{I}$ know of no recording that takes the piece quite as quickly as Britten's markings suggest. John Eliot Gardiner establishes a brisk opening tempo, but loses momentum at the end of the first verse by introducing a ritard not called for in the score.

${ }^{60}$ A possible contemporary instance is "The Instant Gathers," a piano trio by Joan Panetti (a longtime member of the Yale music faculty), which premiered in New York in June 2006. According to the review by Anthony Tommasini in The New York Times of June 5, 2006, "Ms. Panetti said that the title was taken from a Theodore Roethke poem in which the poet warns us that time, the instant, is passing so we had best make the most of it." 
Tommasini went on to write that "she has put the poet's advice to good use in this eventful, intense yet impressively economical 13-minute, three-movement work." The sentiment is authentically Roethkean as well as Horatian, but I have not yet been able to locate the phrase itself in Roethke's work, although I have noted two occurrences of "the instant ages" ("but now the instant ages" in "Give way, ye gates" and "the instant ages on the living eye" in "Infirmity"). A query to the composer was not answered.

${ }^{61}$ It continues to be invoked in non-musical contexts as well: when in April 2010 the London-based Society for the Promotion of Hellenic Studies wished to celebrate the centenary of its sister organization, the Society for the Promotion of Roman Studies, it did so in the form of a Latin ode in sapphic stanzas composed by Armand D'Angour that makes an explicit reference to the Carmen. (Text and translation were published in the Times Literary Supplement for May 28, 2010.)

${ }^{62}$ Carl Loewe (1796-1869) was a prolific composer of songs and choral music. In 1836 he published settings of five odes, or parts thereof (Op. $57=$ Odes 3.3.1-12, 3.12, 3.29.29-56, 3.13, and 2.16.1-8, 13-16, 25-28), arranged for four-part men's chorus. His setting of the Carmen Saeculare followed in 1845; Piperno (1998) 675 states that it was composed in honor of Friedrich Wilhelm IV of Prussia, but the only work by Loewe that I can find with that dedication is his 1848 Festkantate zur Feier der silbernen Hochzeit des Königs Friedrich Wilhelm IV und der Königin Elisabeth; Fleischhauer (1997) 425 suggests instead that the Carmen setting was composed for a celebration at the Gymnasium in Stettin where Loewe was a professor of music. Scores of Loewe's ode settings and of the Carmen are in Draheim-Wille (1985) 106-24. 
${ }^{63}$ A setting by Reger dating to 1900 is mentioned by Piperno (1998) 673, but I have found no trace of it in Reger's collected works.

${ }^{64}$ On the genesis and performance history of this remarkable work, see Carroll (1977).

${ }^{65}$ Baretti (1779) 3-4. That statement probably constitutes an implicit polemic against Bottarelli's two cycles of Horatian cantatas (1757 and 1775), with which Baretti must have been familiar. (See above, 000.) A similar complaint was made by Johann Gottfried Herder, in his Briefe über das Lesen des Horaz, an einen jungen Freund of 1803: "auch wundert es mich wirklich, daß Horaz von unsern Musikmeistern, die doch an guten Texten oft Mangel leiden, so wenig componirt ist" (cited by Draheim-Wille (1985) 1). ${ }^{66}$ Baretti (1779) 12.

${ }^{67}$ Philidor was also an internationally recognized authority on chess, whose treatise L'Analyse du jeu des échecs went through numerous printings in French, English, and German between 1750 and 1900.

${ }^{68}$ The credit (if that is the right word) for assembling the texts in that way belongs to the Jesuit Noël-Etienne Sanadon, who called the result the Polymetrum Saturnium in Ludos Saeculares; it first appeared as part of Sanadon's translation of Horace in 1728. The version set by Philidor reflects a slight revision of Sanadon's order introduced by Philip Francis in his Dublin, 1742 edition of Horace; cf. Carroll (1977) 98-9. The headings to the various sections are cited from the translation of the Polymetrum by Baretti distributed at the first performance. In his Life of Johnson (entry for March 16, 1779), Boswell recalls an occasion on which Johnson was pressed for his opinion of Baretti's translation of the Carmen. Unable honestly to commend it but not wishing to give 
offense, he made the diplomatic reply "Sir, I do not say that it may not be made a very good translation."

${ }^{69}$ See the outline in Carroll (1977) 108-9.

${ }^{70}$ The double fugue for chorus on the stanza beginning Certus undenos (Carm. Saec. 214), though strongly suggestive of an academic exercise in counterpoint, is still one of the work's most distinctive movements.

${ }^{71}$ See below, 000. The recording was made in 1998 but not released until 2007.

${ }^{72}$ The passages set are lines 9-12, 25-8, 37-40, 45-8, and 61-8. The first stanza is marked "maestoso," and the tempo slows to "molto solenne" before the concluding two stanzas.

${ }^{73}$ There is no such dedication in the piano-vocal score published by Ricordi; Piperno (1998) 676 plausibly suggests that Malipiero added a handwritten dedication to a copy of the score presented to Mussolini.

${ }^{74}$ Cf. Marchetti (1975) 402.

${ }^{75}$ Salvatori appears to have been an equal opportunity panegyrist: he also composed a hymn to Trieste (Inno a Trieste, also referred to as the Canto del tricolore), set to music by Luigi Mancinelli (1848-1921) and premiered on March 9, 1919; cf. Mariani (2000) 341. 